\title{
PRELIMINARY SEDIMENTOLOGICAL RESULTS INDICATE A NEW DETAILED STRATIGRAPHY FOR THE FLORINA SEDIMENTARY BASIN AND RELATE THEM WITH $\mathrm{CO}_{2}$ PRESENCE
}

\author{
Karakatsanis S. ${ }^{1}$, Koukouzas N. ${ }^{2}$, Pagonas M. ${ }^{1}$, and Zelilidis A. \\ ${ }^{1}$ University of Patras, Department of Geology, 26500 Patras, Greece, A.Zelilidis@upatras.gr, \\ karastyl@gsrt.gr,pagonas@upatras.gr \\ ${ }^{2}$ C.E.R.T.H., Attica Technology Park, 15310 Ag.Paraskevi Athens. \\ koukouzas@techp.demokritos.gr
}

\begin{abstract}
Drill core analysis showed 41 sedimentary cycles in the sedimentary association of the Neogene to Quaternary Florina Basin, with a total thickness up to 560m. The lower part is the Base formation with an up to $297 \mathrm{~m}$ thick, whereas middle part, Vevi formation is up to $127 \mathrm{~m}$ thick and the upper part which corresponds to Lophon formation is up to $124 \mathrm{~m}$ thick. The beginning of sedimentation in the basin, with alternated sand, clay and conglomeratic beds, with presence of xylite, at the lowermost part of Base formation, indicates a weak tectonic activity and low sedimentation rate. Tectonic activity increased and alluvial fans were formed in the rest part of Base formation. The 21 cycles within alluvial fans could be related mostly with 21 episodes of tectonic activity and sedimentation and less with climatic changes or autocyclic events. Depositional environment changed in the Vevi formation from terrestrial to lacustrine, where lacustrine and fluvio-lacustrine deposits were accumulated. Finally, the basin filled up with terrestrial deposits in the Lophon formation. So, the ratio of subsidence rate/sedimentation rate starts with $<1$, in Base formation, becomes $=1$ in the case of Vevi's formation and finally becomes again $<1$ in Lophon formation. Fluvial and alluvial fan environments can be used as $\mathrm{CO}_{2}$ storage sites, whereas the internal change of stratigraphy in the same environment of sedimentation does not allow the escape of $\mathrm{CO}_{2}$.
\end{abstract}

Key words: sedimentary cycles, alluvial-fans, fluvio-lacustrine environment.

\section{Пврі́̊пчи}

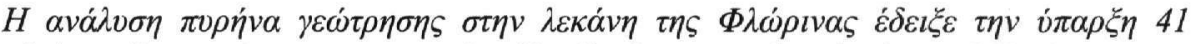

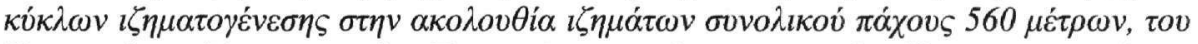

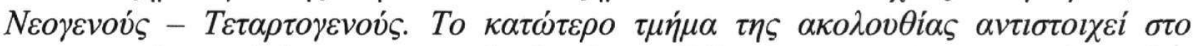

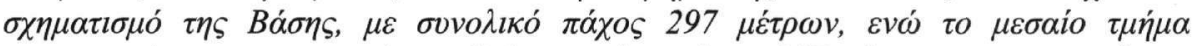

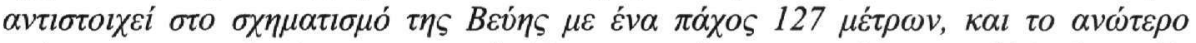

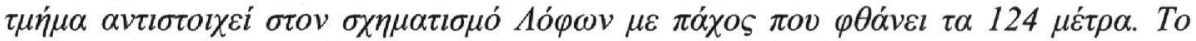

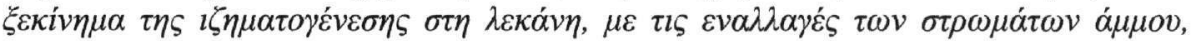




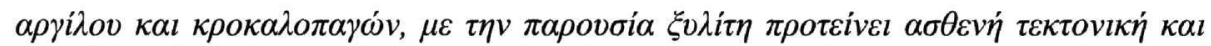

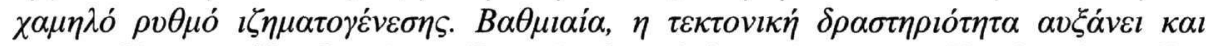

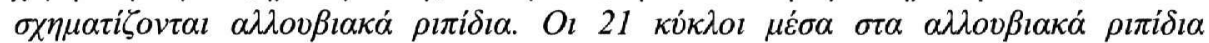

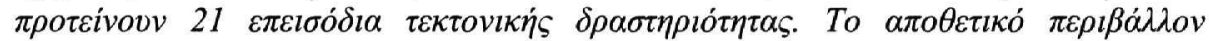

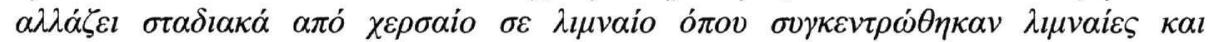

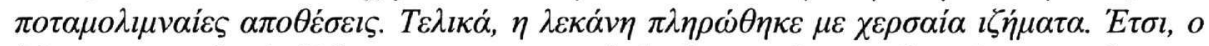

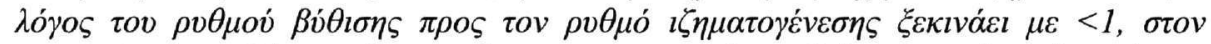

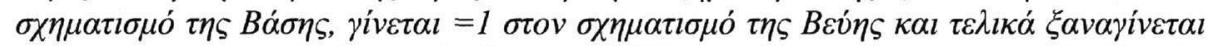

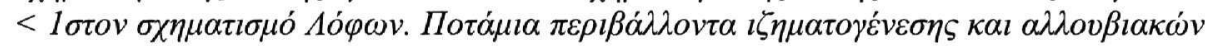

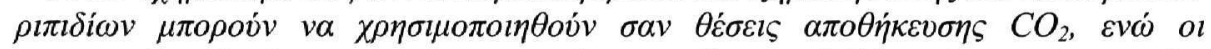

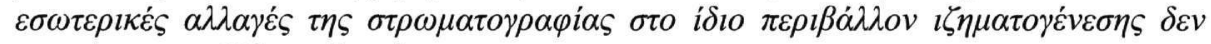

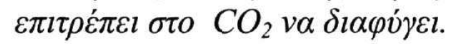

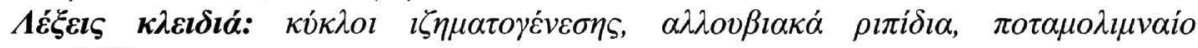
$\pi \varepsilon \rho \imath \beta \dot{\alpha} \lambda \lambda$ ov.

\section{Introduction - Geological Setting}

The studied area is part of the Florina-Amynteon sedimentary basin. It is located in North-West Macedonia (Greece) while is located between the coordinates $40^{\circ} 42^{\circ}-40^{\circ} 54^{\prime}$ latitude and $21^{\circ} 20^{\prime}$ $21^{\circ} 35^{\prime}$ longitude, and it belongs to Pelagonian geotectonic Zone (Pavlidis and Mountrakis 1987) (Fig. 1). The basement is characterized by the metamorphic rocks of Varnounta and Vorras and Carbonate rocks at the eastern margins of the basin (Kilias 1980).

Metamorphic rocks deposited during the Upper Carbiniferous period constitute two complexes, Vorras and Vernon respectively (Mountrakis 1983). The Vorras complex is composed of orthogneiss with relative homogeneous mass of biotitic gneiss, granular banded muscovitic gneiss, and a layer that is composed of mica and amphibolitic schist and phyllites. The Vernon complex is composed by Vitsi-Nemfeon zone with grey, light coloured and white gneiss, Kleisouras zone with alternations of amphibolitic and schistolithic rock, Gneiss plutonic rocks of Kastorias's zone, Sideroxoriou zone with semi-metamorphic and epimetamorphic rocks and Aposkepou zone with arkoses, conglomerates, pelites, phyllites, tuffic rocks.

The studied basin has been filled up by Neogene and Quaternary sediments (Pavlidis and Mountrakis 1987, Fig. 2). According to Pavlidis (1985), Neogene sediments distinguished in the lower part, Base formation, with an up to $200 \mathrm{~m}$ thick, the middle part, Vevi formation up to $50 \mathrm{~m}$ thick, and the upper part, Lophon formation, up to $200 \mathrm{~m}$ thick. These three parts are characterised by the continuous sedimentation from Late Miocene to Pleistocene. Middle part, according to Pavlidis (1985) is synchronous with Vegora formation from Ptolemais basin, and so, the age of this part is estimated as late Miocene - early Pliocene, but it is equal in lithostromatography with the Ptolemais formation with an early Pliocene age (Pavlidis and Mountrakis 1987, Steenbrink et al. 2006). This part is composed of quartz-rich sand, mica layers and grey clay, which at places contains leafs in good condition, followed by layer of lignite which is placed between sand and clay layer. The upper part, due to the presence of some characteristic fossils (e.g. Planorbis, Neritica, Unio, Lymnaeus), was formed during Pliocene, synchronous with lignite deposits of Ptolemais basin (Pavlidis 1985) or could be related with the upper part of Ptolemais basin sediments, because they have the same lithology, with an early Pleistocene age (Pavlidis and Mountrakis 1987, Steenbrink et al. 2006). Quaternary deposits are mostly terrestrial and were characterized by fluviolacustrine, fluvial and alluvial fan environments that developed during early Pleistocene.

Late Miocene is characterized by NE-SW extension (Pavlidis and Mountrakis 1987) whereas a subsequent Pleistocene episode of NW-SE extension resulted in the fragmentation of the initial basin into several sub-basins, i.e., the sub-basins of Florina, Ptolemais and Servia (Pavlidis and Mountrakis 1987, Steenbrink et al. 2006). 


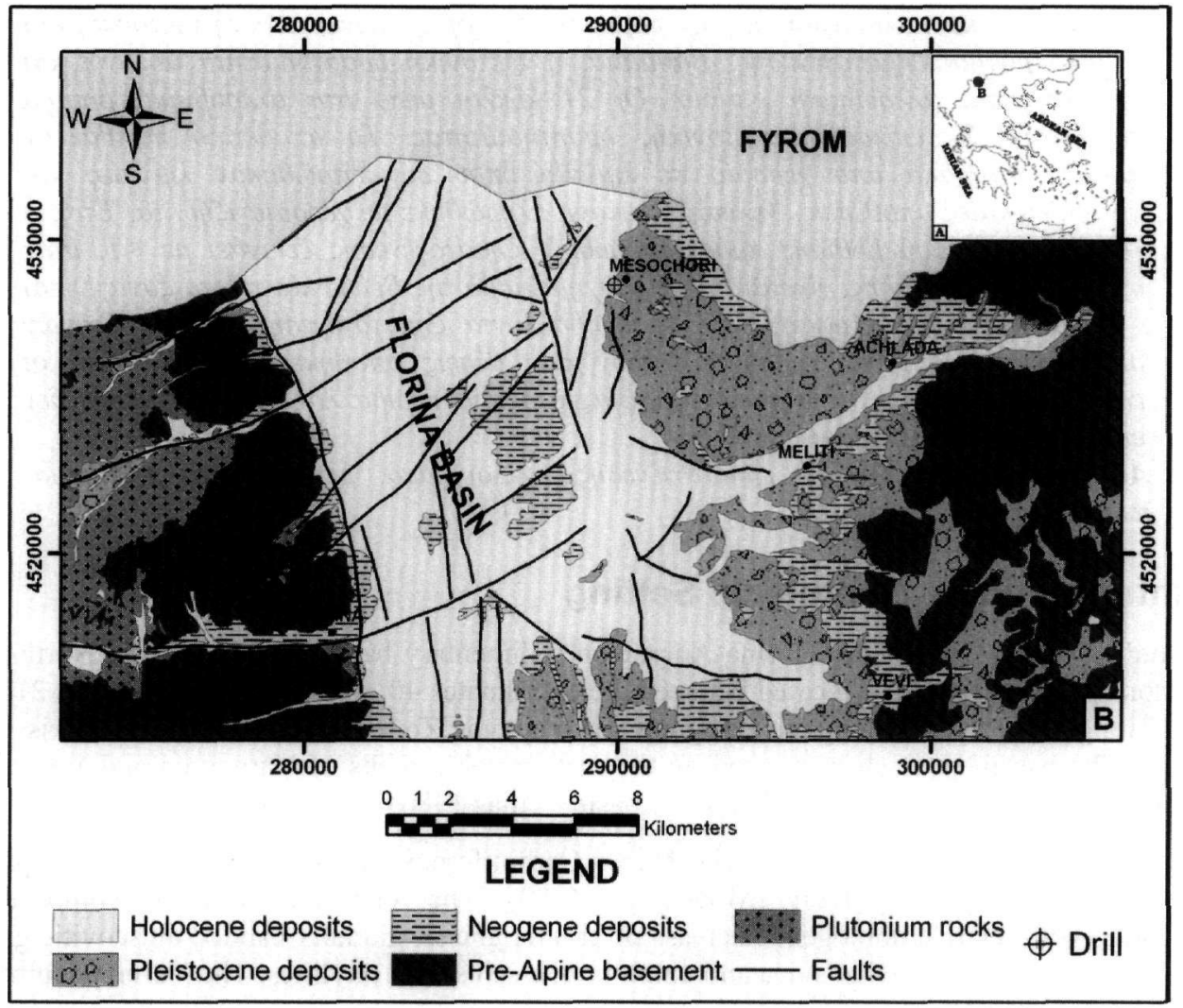

Figure 1 - Geological map of the studied area, modified from I.G.M.E. Florina and Vevi geological maps

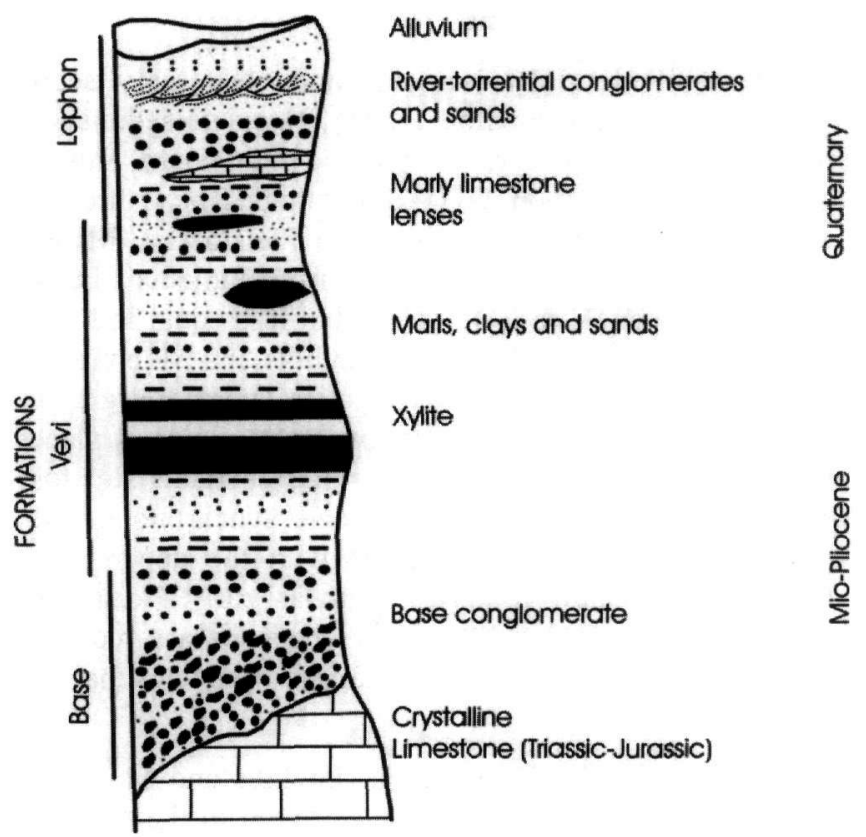

Figure 2 - Stratigraphy of the studied basin, not in scale, according to Pavlidis (1985) 
Accrding to Vetoulis (1951), Quaternary deposits occupy a great part of the basin and cover partially or totally the Tertiary formations represented by Pleistocene (Diluvium) and Holocene (Aluvium) deposits while consists of sands, muds, quartz-rich conglomerates and conglomerates. Pleistocene (Diluvium) sediments composed of coarse quartz-rich conglomerates, and mud products as a result of erosion, which was caused by torrents while their thickness varies from 2 up to $5 \mathrm{~m}$. Below them there is a 10-30 metres thick layer of muddy sand. Holocene (Aluvium) consist of fluvial deposits and accretions of muddy matter, quartz-rich sand, clays with fluvial fossils such as gasteropods.

The aim of the present work is to present the detailed lithostratigraphy of the sedimentary basin of Florina based on a drill core at the eastern margin of the basin and to introduce a model of the basin evolution from Neogene to present. Age determination of the selected samples and detailed sedimentological analysis of them will establish the exact model of Florina basin evolution, taking into account ages, sedimentological results and published structural data.

\section{Sedimentological description of drill core in Mesochori}

A drill core, with a length of 570meters, divided into 8 parts (A: 0-124 m., B: 124-152 m., C: 152251 m., D: 251-376 m., E: 376-430 m., F: 430-548 m., G: 548-560 m., H: >560 m.) (Fig. 3). These divition into 8 parts based on different lithology, from one part to the other, whereas cycles boundary based on the abrupt change from the one lithology to the other. These eight parts show not only their length but also their depth from the surface. The lowermost part, which was met $>560 \mathrm{~m}$ from the surface, is referred as basement. According to Pavlidis (1985) and our analysis there are three main groups of rocks, the sediments above lignite $(0-124 \mathrm{~m})$ which belongs to Lophon formation (Part A), the lignite layers (124-152 m) and the underlying them deposits as far as the depth of $251 \mathrm{~m}$, that belongs to the Vevi formation (Parts B and C), and sediments below them $(251-560 \mathrm{~m})$ which related with the Base formation (Parts D, E, F and G). A detailed description (Fig. 3) is given below, from top to bottom.

Part A, 0-124 m: This part is composed of 4 cycles with an upward increase in grain size and decrease in sedimentary thickness of each cycle. At the top third and fourth cycle consists of conglomerates whereas first and second cycle consists of sand. Their thickness from lower to upper cycle is $50.5 \mathrm{~m}$ (48 m of mud- 2.5 of sand), $36.5 \mathrm{~m}$ (33.5 m of mud, $3 \mathrm{~m}$ of sand), $30 \mathrm{~m}$ ( $3 \mathrm{~m}$ of mud, $8 \mathrm{~m}$ of sand, $9 \mathrm{~m}$ of conglomerates), $7 \mathrm{~m}$ ( $6 \mathrm{~m}$ of sand, $1 \mathrm{~m}$ of conglomerates).

Moreover, an aquifer appeared between 102-106m from the surface.

Part B, 124-152 m: In this part 11 cycles with alternated clays and sand were recognized. Lignite was detected at the upper part of 5 cycles. Thickness of the cycles, from lower to the upper, are the following: $1 \mathrm{~m}(0.5 \mathrm{~m}$ of mud, $0.5 \mathrm{~m}$ of lignite $), 3 \mathrm{~m}$ ( $1 \mathrm{~m}$ of mud $-2 \mathrm{~m}$ of sand $), 1.5 \mathrm{~m}$ ( $1 \mathrm{~m}$ of mud $-0.5 \mathrm{~m}$ of sand), $1.5 \mathrm{~m}$ ( $0.5 \mathrm{~m}$ of mud $-1 \mathrm{~m}$ of sand), $6 \mathrm{~m}$ ( $1.5 \mathrm{~m}$ of mud $-4.5 \mathrm{~m}$ of sand), 2 $\mathrm{m}$ ( $1 \mathrm{~m}$ of mud, $1 \mathrm{~m}$ of lignite), $2.5 \mathrm{~m}$ ( $2 \mathrm{~m}$ of sand $-0.5 \mathrm{~m}$ of lignite), $1.5 \mathrm{~m}$ ( $1.1 \mathrm{~m}$ of sand -0.4 $\mathrm{m}$ of lignite), $4.5 \mathrm{~m}$ (1.5 $\mathrm{m}$ of sand $-3 \mathrm{~m}$ of lignite), $1.7 \mathrm{~m}$ (1.3 $\mathrm{m}$ of sand $-0.4 \mathrm{~m}$ of lignite), $2.8 \mathrm{~m}$ ( $2 \mathrm{~m}$ of sand $-0.8 \mathrm{~m}$ of lignite).

In general, it is noticed an increase of grain size and lignite thickness from the lower to upper cycle of this part.

In last cycle, a $\mathrm{CO}_{2}$ accumulation was detected. The accumulation was found in sands under the lignite layer. The accumulation has already been exploited.

Part C, 152-251 m: This part it consist by 10 cycles of alternated sand and clay with an upward increase in grain size from the lower to upper cycle. Between 3-24 m is noticed the decrease of cycle thickness and sand's thickness from the lower to upper cycle. 


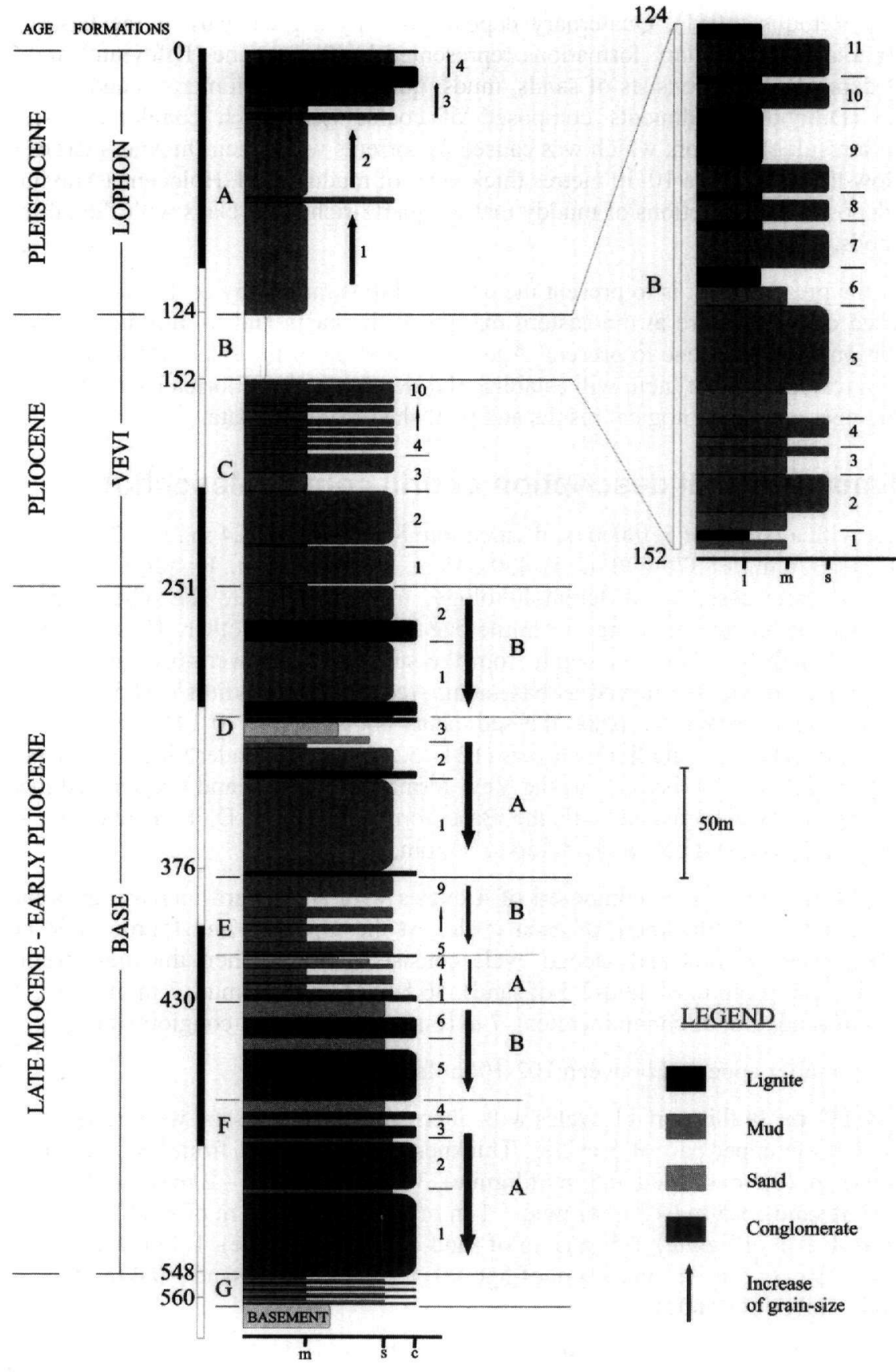

Figure 3 - Stratigraphy of the Florina basin, based on the drill core analysis of this work. Horizontal scale at the base is for lithology, $m=$ mud, $s=s a n d$ and $c=$ conglomerates. Numbers and letters in each Part show cycles and sequences respectively

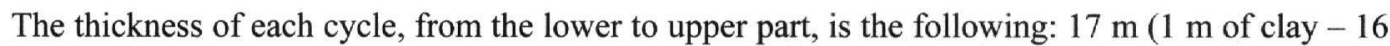
$\mathrm{m}$ of sand), $24 \mathrm{~m}$ ( $1 \mathrm{~m}$ of clay $-23 \mathrm{~m}$ of sand), $16 \mathrm{~m}$ ( $8 \mathrm{~m}$ of clay $-8 \mathrm{~m}$ of sand), $4 \mathrm{~m}$ ( $2 \mathrm{~m}$ of clay $-2 \mathrm{~m}$ of sand), $3 \mathrm{~m}$ ( $1 \mathrm{~m}$ of clay $-2 \mathrm{~m}$ of sand), $4 \mathrm{~m}$ ( $1 \mathrm{~m}$ of clay $-3 \mathrm{~m}$ of sand), $4 \mathrm{~m}$ ( $1 \mathrm{~m}$ of clay $-3 \mathrm{~m}$ of sand), $6 \mathrm{~m}$ ( $3 \mathrm{~m}$ of clay $-3 \mathrm{~m}$ of sand), $9 \mathrm{~m}$ ( $1 \mathrm{~m}$ of clay $-8 \mathrm{~m}$ of sand), $2 \mathrm{~m}$ ( $1 \mathrm{~m}$ of clay $-1 \mathrm{~m}$ of sand). 
In the sand of the lower cycle, which has thickness of $17 \mathrm{~m}$, an aquifer was detected.

Part D, 251-376 m: 6 cycles which consist of conglomerates and sand were detected while their thickness varies from 3 up to $42 \mathrm{~m}$. These cycles constitute two sequences with decrease in grain size and thickness from the lower to upper sequence of this part.

The cycles and sequences are quoted below. A: $42 \mathrm{~m}$ ( $2 \mathrm{~m}$ of conglomerates $-40 \mathrm{~m}$ of sand), $15 \mathrm{~m}$ ( $3 \mathrm{~m}$ of conglomerates $-10 \mathrm{~m}$ of sand $-2 \mathrm{~m}$ of clay), $9 \mathrm{~m}$ ( $3 \mathrm{~m}$ of medium grain size sand $-6 \mathrm{~m}$ of fine sand), $3 \mathrm{~m}$ ( $2 \mathrm{~m}$ of conglomerates $-1 \mathrm{~m}$ of sand), B: $32 \mathrm{~m}$ ( $6 \mathrm{~m}$ of conglomerates $-26 \mathrm{~m}$ of sand), $24 \mathrm{~m}$ ( $9 \mathrm{~m}$ of conglomerates $-15 \mathrm{~m}$ of sand).

Four natural $\mathrm{CO}_{2}$ accumulations from depth $296 \mathrm{~m}$ up to $334 \mathrm{~m}$ (296-306 m, 310-312 m, 322-331 $\mathrm{m}, 335-338 \mathrm{~m})$ and 2 aquifers $\left(301-304 \mathrm{~m}, 331-338 \mathrm{~m}\right.$ ) were detected. An additional $\mathrm{CO}_{2}$ accumulation exists at 366-372 $\mathrm{m}$ depth. These formations appeared in coarse components without an upper layer of fine materials which acts as a cap rock.

Part E, 376-430 m: 9 cycles of alternation of sand and cycle compose this part. Their thickness ranges from 0.5 to $9 \mathrm{~m}$. These cycles constitute two sequences with decrease in grain size from the lower to upper sequence of this part.

The cycles and sequences are quoted below. A: $7.5 \mathrm{~m}$ (of conglomerates-sand-clay), $0.5 \mathrm{~m}$ (of sand-clay), $6 \mathrm{~m}$ (of sand-clay), $5 \mathrm{~m}$ (of sand: coarse-medium-fine grain size), B: $2 \mathrm{~m}$ (of conglomerates-sand), $9 \mathrm{~m}$ (of sand-clay), $6 \mathrm{~m}$ (of sand-clay), $9 \mathrm{~m}$ (of sand-clay), $9 \mathrm{~m}$ (of sand).

Four accumulations of $\mathrm{CO}_{2}$ in coarse components without an upper rock layer which acts as a cap rock were detected at depths from $380 \mathrm{~m}$ up to $409 \mathrm{~m}$.

From $410 \mathrm{~m}$ up to the end of this part, a saturated water table layer was recognized.

Part F, 430-548 m: There are 6 cycles which consist of conglomerates and sand. Sand's proportion is greater in the upper than in the lower cycle. These cycles constitute two sequences with decrease in grain size from the lower to upper sequence of this part. The thickness of the cycles and the proportion of conglomerates/sand decreased from the lower to the upper cycle. The cycles from lower to upper are composed of A: $38 \mathrm{~m}$ ( $36 \mathrm{~m}$ of conglomerates $-2 \mathrm{~m}$ of sand), $22 \mathrm{~m}$ ( $20 \mathrm{~m}$ of conglomerates $-2 \mathrm{~m}$ of sand), $8 \mathrm{~m}$ ( $5 \mathrm{~m}$ of conglomerates $-3 \mathrm{~m}$ of sand), $8 \mathrm{~m}$ ( $3 \mathrm{~m}$ of conglomerates $-5 \mathrm{~m}$ of sand), B: $27 \mathrm{~m}$ ( $22 \mathrm{~m}$ of conglomerates $-5 \mathrm{~m}$ of sand), $16 \mathrm{~m}$ (9 m of conglomerates $-7 \mathrm{~m}$ of sand).

Part G, 548-560 m: Alterations of sand-clay and conglomerates with the presence of xylite is noticed.

Part H, >560 m: At depth $562 \mathrm{~m}$ from the surface appears a soil layer which is up to $2 \mathrm{~m}$ thick, while under this level appears the basement. The basement consists of gneiss and quartzite.

\section{Interpretation}

According to Pavlidis (1985) and our analysis Part A belongs to Lophon formation, Parts B and C belongs to the Vevi formation, whereas Parts D, E, F and G belongs to the Base formation. Specially:

Part A from 0-124 m: Sediments of this part were formed in a lacustrine and a fluvial environment. The evolution of the four cycles indicates the activation of the basin four times during the development of the lacustrine environment; two lower cycles which fully deposited and "closed" the lake and two other cycles where the deposition was gradually. The two lower cycles seem to correspond to conditions similar to lake while the two upper cycles correspond to fluviolacustrine conditions. Furthermore the variation of cycles' thickness and the decrease of thickness upwards indicate the deactivation of the deposition from older to younger deposits. 
Part B from 124-152 m: According to Pavlidis (1985) this is the upper part of Vevi's formation which is of Late Miocene-Early Pliocene age and formed in a lacustrine environment. According to Pavlidis and Mountrakis (1987) and Steenbrink et al. (2006) description of this Part seems to be equal with Ptolemais Formation of Ptolemais basin which formed during Early Pliocene.

Part C from 154 to $251 \mathrm{~m}$ : According to Pavlidis (1985), this part belongs to the lower part of Vevi's formation. The cycle's structure and thickness, from the lower to upper of this part shows that there are 10 stages of deposition in the basin. Its seems that the dynamic of the deposition was decreased from the lower to the upper parts, while it looks that the basin remains as lake for smaller period of time and was gradually deposited resulted to conglomerates of greater thickness compared to the fine grained sediments.

Part D from 251-376 m: The cycles' structure and their grain size show that correspond to the formation of Base, formed in a terrestrial environment. The two series of sediments indicate that two main events took places which are both related with events of minor importance. It seems that these series correspond to deposits which gradually feed the basin.

Part F from 430 to $548 \mathrm{~m}$ : These sediments seem to be deposited by debris flows in alluvial fan environments. The structure of cycles and sequences shows the progressive reduction of tectonic activity but also the renewal of tectonics of the second sequence. Examining this part (430-548 $\mathrm{m}$ ) together with the overburden part (376-430 m), then probably the overburden sector constitutes the shifted part of a different alluvial fan that was formed in a different place. However, if this part (376-430 m) is related, in terms of genesis, with the overburden part (251-376 m) which was of fluvial origin, then this part (376-430 m) might correspond to sediments of parallel deposition. In both cases immigration of sedimentation process and source of supply from western to eastern parts appears.

Part G from 458 to $560 \mathrm{~m}$ : The sediments of this lower stratigraphic part indicate the beginning of sedimentation in a basin where its tectonic activity is weak and the sedimentation rate is low, due to the pure drainage pattern when the basin was formed.

Part $\mathrm{H}>\mathbf{5 6 0} \mathrm{m}$ : Basement with metamorphic rocks

\section{Discussion}

Florina basin is part of the initial Florina-Ptolemais-Servia basin which formed due NE-SW late Miocene extension (Pavlidis and Mountrakis 1987, Steenbrink et al. 2006). Fragmentation of this basin took place during early Pleistocene and due to the NW-SE extension (Pavlidis and Mountrakis 1987). Taking into account the above evolution we could relate sedimentation pattern of the Ptolemais basin to the studied Florina basin. So, the $600 \mathrm{~m}$ total thickness of sediments as referred by Steenbrink et. al. (2006) for the Ptolemais basin seems to be equal with the $560 \mathrm{~m}$ total thickness of the studied Florina basin. In detail, the $300 \mathrm{~m}$ thickness of Komnina formation at the lower stratigraphic part of Ptolemais basin seems to be equal with the $297 \mathrm{~m}$ thick of Base formation in the Florina basin, whereas the $100 \mathrm{~m}$ thick of Ptolemais formation in Ptolemais basin seems to be equal with the $127 \mathrm{~m}$ thick of Vevi formation in Florina basin.

According to the above hypothesis we could relate also the time of sedimentation and the depositional environments between the two adjacent basins Ptolemais and Florina. In the case that sedimentation rate is equal in both basins, and this could be indicated due to the fact that from late Miocene to Pliocene the basin was unique, then the Base Formation age of Florina basin could be equal with the age of Komnina formation of Ptolemais basin and it is late Miocene to early Pliocene, whereas Vevi formation in the studied basin could be equal with the Ptolemais formation in Ptolemais basin and it is early Pliocene. Finally, the uppermost Lophon formation is equal with the uppermost formation of Ptolemais basin and it is early Pleistocene. In this case we have a change of the Pavlidis (1985) suggested age for the Vevi formation which was referred as late Miocene-early Pliocene. According to this scenario most of the cycles formed within the 
sediments could be related with tectonic activity and tectonic pulses. Tectonic activity produced the relief in order to have an active source.

The second hypothesis is to accept as correct the mentioned age for the Vevi formation and in this case we have different sedimentation rates from one basin to the other and different depositional environments. When we have only $300 \mathrm{~m}$ terrestrial deposits in Ptolemais formation during Late Miocene-early Pliocene (Komnina formation), we have $425 \mathrm{~m}$ thick sediments with terrestrial and lacustrine deposits in Florina basin (Base and Vevi formations); whereas when we have $100 \mathrm{~m}$ thick lacustrine deposits in Ptolemais basin during early Pliocene there is no sedimentation in Florina basin. Taking into account this second hypothesis with different depositional conditions along the unique basin then we could indicate that many of the cycles within the Vevi's formation lacustrine deposits represent autocyclic events such as climatic changes, as this also suggested from Steenbrink et al. (2006) for Ptolemais formation in Prolemais basin.

Finally, as the unique basin subdivided into three sub-basins during early Pleistocene, it seems that we have the same sedimentological pattern in the two adjacent basins with the same terrestrial deposits.

\section{Conclusions}

1. Drill core analysis showed 41 sedimentary cycles in the sedimentary association of the Neogene to Quaternary Florina Basin, with a total thickness up to $560 \mathrm{~m}$.

2. The beginning of sedimentation in the basin, from $548-560 \mathrm{~m}$, with alternated sand, clay and conglomeratic beds, with presence of xylite indicates a weak tectonic activity and low sedimentation rate.

3. From the depth of $251 \mathrm{~m}$ and up to $548 \mathrm{~m}$, appears the Base formation, with a total thickness of $297 \mathrm{~m}$, formed in a terrestrial environment, probably stacked alluvial-fans, which become fluvial upwards. 21 cycles within alluvial fans indicate 21 episodes of tectonic activity and sedimentation. The upward change from alluvial fans to fluvial deposits indicates the gradual change from more active to less active tectonic activity. Moreover, the Base formation includes the $\mathrm{CO}_{2}$ accumulations which are found in fine sands and mostly accumulated in the fluvial environment.

4. Between $124 \mathrm{~m}$ and $25.1 \mathrm{~m}$, Vevi formation is present which is developed in a lacustrine environment. 21 cycles within this formation and lignite horizons in the upper part of the sedimentary sequence indicate that sedimentation rate is equal to the subsidence rate and every time when fault activity create space sedimentation filled up the space. Total lignite thickness is up to $6.6 \mathrm{~m}$ formed in the upper part of 6 cycles within a total sedimentary association of $28 \mathrm{~m}$ thick.

5. The uppermost sediments, between the surface and the depth of $124 \mathrm{~m}$, are the Lophon formation of Pliocene-Quaternary age, accumulated in a fluviolacustrine environment.

Generally, the change from alluvial fans to lacustrine and finally to fluvial deposits could be related with the ratio of subsidence rate/sedimentation rate. So, the above changes could be show that the basin sedimentation started with a ratio $<1$, becomes $=1$ in the case of Vevi's formation and finally becomes again $<1$. This results to the covering of the lake with sediments.

$\mathrm{CO}_{2}$ storage sites mostly referred to fluvial and alluvial fan environments and a detailed study (i.e. porosity) could be relating these environments with future storages of $\mathrm{CO}_{2}$. Moreover, the internal change of stratigraphy in the same environment of sedimentation does not allow the escape of $\mathrm{CO}_{2}$. However, it should be a connection between the presence of $\mathrm{CO}_{2}$ with aquifers and the height of column of water and how much the hydrostatic pressure increases the trapping of gases in the sediments. 


\section{Acknowledgments}

We would like to thank I.G.M.E. for the permission to use the drill core data for detail sedimentological analysis. The authors are indebted the reviewer Dr. Steenbrink for his detailed suggestions and corrections.

\section{References}

Kilias, A., 1980. Geological and tectonic study of eastern Varnountas area (NW Macedonia), $P h D$ Thesis, University of Thessaloniki, 27lpp.

Mountrakis, D., 1983. The geological structure of northern Pelagonian zone and geotectonic evolution of internal Hellenides. Dissertation for readership, University of Thessaloniki, 289 pp.

Pavlidis, S., 1985. Neotectonic evolution of Florina - Vegoritida - Ptolemais basins (W. Macedonia), PhD Thesis, University of Thessaloniki, 265pp.

Pavlidis, S.B., and Mountrakis, D.M., 1987. Extensional tectonics of northwestern Macedonia, Greece, since the late Miocene, Journal of Structural Geology, 9., 385-392.

Steenbrink, J., Hilgen, F.J., Krijgsman, W., Wijbrans, J.R., and Meulenkamp, J.E., 2006. Late Miocene to Early Pliocene depositional history of the intramontane Florina-ProlemaisServia Basin, NW Greece: Interplay between orbital forcing and tectonics. Palaeog. Palaeoc. Palaeoec., 238, 151-178.

Vetoulis, D., 1951. The lignitic Amynteon - Vegora basin, Geol. Anagn., IGEY, Athens, No14, 130. 